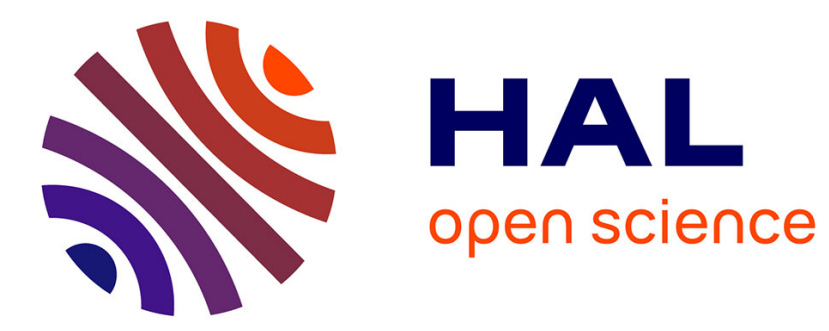

\title{
ORDERING IN FLUORITE-RELATED OXIDE SYSTEMS
}

\author{
H. Rossell, H. Scott
}

\section{To cite this version:}

H. Rossell, H. Scott. ORDERING IN FLUORITE-RELATED OXIDE SYSTEMS. Journal de Physique Colloques, 1977, 38 (C7), pp.C7-28-C7-31. 10.1051/jphyscol:1977704 . jpa-00217205

\section{HAL Id: jpa-00217205 https://hal.science/jpa-00217205}

Submitted on 1 Jan 1977

HAL is a multi-disciplinary open access archive for the deposit and dissemination of scientific research documents, whether they are published or not. The documents may come from teaching and research institutions in France or abroad, or from public or private research centers.
L'archive ouverte pluridisciplinaire HAL, est destinée au dépôt et à la diffusion de documents scientifiques de niveau recherche, publiés ou non, émanant des établissements d'enseignement et de recherche français ou étrangers, des laboratoires publics ou privés. 


\title{
ORDERING IN FLUORITE-RELATED OXIDE SYSTEMS
}

\author{
H. J. ROSSELL $\left({ }^{*}\right)$ and H. G. SCOTT \\ CSIRO Division of Tribophysics, Engineering Ceramics and Refractories Laboratories, \\ P.O. Box 4331, Melbourne 3001, Australia
}

\begin{abstract}
Résumé. - La mise en ordre dans les phases fluorine non stoechiométriques $\left(\mathrm{MO}_{2-x}\right)$ peut entraîner la mise en ordre complète ou partielle des lacunes anioniques. La mise en ordre anionique complète a pour résultat la formation de surstructures apparentées à la fluorine qui peuvent présenter aussi des degrés différents de mise en ordre cationique. La mise en ordre anionique partielle provoque une diffraction diffuse d'électrons ; cette diffusion peut être interprétée dans un modèle de microdomaines ordonnés cohérents, ou bien en termes d'occupations de site corrélées dans une matrice statistique homogène.
\end{abstract}

\begin{abstract}
Ordering in the defect fluorite $\mathrm{MO}_{2-x}$ phases may involve either complete or partial ordering of the anion vacancies. Complete anion ordering results in the formation of fluorite-related superstructures which may exhibit varying degrees of cation ordering also. Partial anion ordering results in diffuse electron diffraction effects, which may be interpreted in terms of coherent ordered microdomains, or in terms of correlated site occupancies in a statistically homogeneous matrix.
\end{abstract}

1. Introduction. - The fluorite structure, $\mathrm{CaF}_{2}$ type, Fm $3 \mathrm{~m}$, consisting of a face-centred cubic array of cations with anions in all of the tetrahedral holes is adopted by the oxides $\mathrm{MO}_{2}$ of large-radius tetravalent metals. A grossly non-stoichiometric phase $\mathrm{MO}_{2-x}, 0<x<0.4$, of fluorite structure may be produced in many oxide systems by substitution of the tetravalent cations by those of lower valence, either by reduction, e.g. $\mathrm{PrO}_{2-x}$, or by solid solution, e.g. $\mathrm{Ca}_{x} \mathrm{Zr}_{1-x} \mathrm{O}_{2-x}[1,2]$.

In these defect fluorite materials, the cation sublattice is totally occupied in essence, while the anion deficiency is accommodated as vacant lattice sites. This structure accounts for a characteristic property : Anion movement (diffusion, conductivity) is rapid even at relatively low temperatures, whereas cation movements are slow and occur at high temperature. These materials thus differ in structure from the oxides of the smaller-radius metals, where the anion substructure is close-packed, and any deviations from stoichiometry are absorbed in the cation array.

2. Ordering in the defect fluorite phase - States of disorder, partial or complete order of cation type or of anion vacancies, or both, can be imagined to occur in the defect fluorite phase, giving rise to new structures. Not all of these have been observed in actual systems, however.

2.1 StRUCTURES INVOLVING COMPLETE VACANCY ORDERING. - Fluorite-related superstructure phases of narrow homogeneity range often appear at relatively

(*) Presenting author. low temperature within a defect fluorite phase field. Numerous examples, some of which belong to a series $\mathrm{M}_{n} \mathrm{O}_{2 n-2}$, are known.

The structures of a few of these, e.g. $\mathrm{In}_{2} \mathrm{O}_{3}$ [3]. $\mathrm{UY}_{6} \mathrm{O}_{12}$ [4] and $\mathrm{Zr}_{3} \mathrm{Yb}_{4} \mathrm{O}_{12}$ [5] of $\mathrm{M}_{7} \mathrm{O}_{12}$ type, the pyrochlore $\mathrm{Cd}_{2} \mathrm{Nb}_{2} \mathrm{O}_{7}$ [6] and the mineral calcirtite, $\mathrm{CaZr}_{3} \mathrm{TiO}_{9}$ [7] have been determined from single crystal data. In general, however, only powder data are available, from which some structures, e.g. $\mathrm{Zr}_{5} \mathrm{Sc}_{2} \mathrm{O}_{13}$ [8] $\mathrm{Pr}_{7} \mathrm{O}_{12}$ [9] and numerous pyrochlores have been determined. The structures of $\mathrm{Ca}_{2} \mathrm{Hf}_{7} \mathrm{O}_{16}$ [10], $\mathrm{CaHf}_{4} \mathrm{O}_{9}$ and $\mathrm{Ca}_{6} \mathrm{Hf}_{19} \mathrm{O}_{44}$ [11], some ternary $\mathrm{M}_{7} \mathrm{O}_{12}$ compounds [12] and $\mathrm{M}_{4} \mathrm{O}_{7}$ compounds (unpublished) were determined from powder data supplemented by the unambiguous subcellsupercell relationships and symmetry information afforded by single crystal electron diffraction patterns obtained with an electron microscope.

In the known superstructures, all anion vacancies occur in pairs separated by a $1 / 2\langle 111\rangle$ fluorite lattice vector with a cation in between, so that with anion relaxation, this cation becomes octahedrally coordinated by $\mathrm{O}$. The cation-vacancy pair complex may be isolated, as in $\mathrm{M}_{7} \mathrm{O}_{12}$, or linked into zig-zag chains (pyrochlore), helical chains $\left(\mathrm{Ca}_{6} \mathrm{Hf}_{19} \mathrm{O}_{44}\right)$ or clusters $\left(\mathrm{CaHf}_{4} \mathrm{O}_{9}\right)$. The linking is such that no vacancy approaches another closer than the $1 / 2\langle 111\rangle$ fluorite separation, with the exception of the C-type rare-earth oxide structure $(25 \%$ vacancies $)$ where $1 / 2\langle 110\rangle$ separations occur.

Cation ordering is linked to the vacancy ordering in that it is the smallest available cation that is octahedrally coordinated. The remainder are either 8 -fold 
coordinated, as in the parent structure, or 7-fold, or both. The concept of coordination polyhedra can be a useful way of describing these structures and classifying them geometrically $[14,15]$. If cation ordering occurs, it must be because the system can overcome the effects of configurational entropy by the decrease in enthalpy arising from optimisation of $\mathrm{M}-\mathrm{O}$ band strengths. Therefore it is often possible to correlate ordering effects with cationic radii.

Depending on the particular superstructure, cation types may be ordered completely or partially, or disordered, as illustrated in the following examples.

2.1.1 For $\mathrm{CaHf}_{4} \mathrm{O}_{9}, \mathrm{Ca}_{2} \mathrm{Hf}_{7} \mathrm{O}_{16}$ and $\mathrm{Ca}_{6} \mathrm{Hf}_{19} \mathrm{O}_{44}$, the cations are completely ordered : All $\mathrm{Ca}$ cations, which are the larger, are in 8-fold coordination, and the $\mathrm{Hf}$ may be 6- or 7-fold coordinated. At about $1400{ }^{\circ} \mathrm{C}$, these compounds disorder to defect fluorite.

2.1.2 The $\mathrm{M}_{7} \mathrm{O}_{12}$ superstructure has a rhombohedral $(R \overline{3})$ unit cell $13 / 4$ times the volume of the subcell. One seventh of the cations are in 6-fold coordination on a site of trigonal symmetry; the remainder are equivalent, and are in 7 -fold coordination. Four levels of cation ordering may be displayed :

a) complete order, as in $\mathrm{UY}_{6} \mathrm{O}_{12}$,

b) partial order, as in $\mathrm{Zr}_{3} \mathrm{Er}_{4} \mathrm{O}_{12}$, where the trigonal site is occupied by the smallest available cation type, and the remaining cations occupy the general site at random,

c) partial order as in $\mathrm{Hf}_{3} \mathrm{Sc}_{4} \mathrm{O}_{12}$, where all sites are occupied randomly by $\mathrm{Hf}$ and $\mathrm{Sc}$, but at the trigonal site, $[\mathrm{Hf}] /[\mathrm{Sc}]>3 / 4$,

d) complete disorder as in $\mathrm{Zr}_{3} \mathrm{Sc}_{4} \mathrm{O}_{12}$, where all sites have $[\mathrm{Zr}] /[\mathrm{Sc}]=3 / 4$. The conditions in $c$ ) and d) may be correlated with the essentially equal radii of the cations.

The phase $\mathrm{Zr}_{5} \mathrm{Mg}_{2} \mathrm{O}_{12}$ formed during quenching from the high-temperature fluorite phase field [16] is also of type $d$ ). It is metastable and will not survive annealing : Its formation during a brief period is a consequence of the similar cationic radii, high anionic mobility and the stability of the vacancy-pair complex.

All these stable $\mathrm{M}_{7} \mathrm{O}_{12}$ compounds will undergo a reversible transition to the defect fluorite structure at elevated temperatures. The transition for cationordered ternary compounds is slow ( 2 days at $1500^{\circ} \mathrm{C}$ for $\mathrm{Zr}_{3} \mathrm{Er}_{4} \mathrm{O}_{12}$ ) in keeping with the low cation mobilities, but it is fast and occurs at lower temperatures for the binary compounds and $\mathrm{Zr}_{3} \mathrm{Sc}_{4} \mathrm{O}_{12}$, because in these, the cations do not have to move.

Measurements of anionic conductivity in $\mathrm{Zr}_{3} \mathrm{Er}_{4} \mathrm{O}_{12}$ made in our laboratory have shown that the ordered compound has low conductivity, i.e. very little vacancy disorder up to $1500{ }^{\circ} \mathrm{C}$, that the cation order and vacancy order are so linked that both are destroyed together at the disorder transition $\left(1500^{\circ} \mathrm{C}\right)$ when the conductivity rises sharply by several orders of magnitude, and that the cation-vacancy pair complex is stable to temperatures well above those at which anion mobility is appreciable in the disordered phase of this composition (retained metastably by rapid cooling from above $1500^{\circ} \mathrm{C}$ ).

2.1.3 The pyrochlore structure, Fd3m, has a unit cell that is derivable from an array of $2 \times 2 \times 2$ fluorite cells by ordering of cations and omission of one eighth of the anions in an ordered way. Oxide pyrochlores have the formula $\mathrm{A}_{2} \mathrm{~B}_{2} \mathrm{O}_{7}$ : The $\mathrm{A}$ cation is in 8-fold coordination by $\mathrm{O}, \mathrm{B}$ is in 6-fold coordination, and one seventh of the anions are crystallographically distinct. Usually the radius ratio of the cations lies in the range 1.2-1.6, and there are restrictions on the individual radii as well $[17,18]$. Several types of disorder have been reported to occur in pyrochlores.

a) Isomorphous replacement of cations is very common. Either or both of the A and B sites may be occupied randomly by different cation species under relaxed radius restrictions, provided that the distinction between large $A$ and smaller $B$ cations is preserved, and the sum of $\mathrm{A}$ and $\mathrm{B}$ valencies is 7 .

b) Some phases of formula $\mathrm{A}_{3} \mathrm{BO}_{7}$ have been reported to be pyrochlores, implying random population of A and B cations at the B site. The published evidence for this is not conclusive, and our own studies of such materials show that they have fluoriterelated structures quite distinct from pyrochlore.

c) Some pyrochlores, e.g. $\mathrm{Gd}_{2} \mathrm{Zr}_{2} \mathrm{O}_{7}$ exhibit a reversible order-disorder transition to the defect fluorite phase at elevated temperatures : As may be expected from the low cation mobilities, the hightemperature form may be retained on quenching. For $\mathrm{B}=\mathrm{Zr}, \mathrm{A}=$ rare earth, the disordering temperature increases with increasing radius of $A$ until melting intervenes in the case of $\mathrm{A}=\mathrm{Nd}$, La [19].

d) The pyrochlore structure may be described alternatively in terms of a three-dimensional framework of corner-linked $\mathrm{BO}_{6}$ octahedra, of overall composition $\mathrm{BO}_{3}$, with the $\mathrm{A}$ cations and the remaining $\mathrm{O}$ located in large tunnel-like interstices. Although it has been asserted that the $\mathrm{A}$ cations and extra $\mathrm{O}$ are essential to the structure [20], there have been subsequent reports of grossly defective pyrochlores [21, 22], particularly in systems involving $\mathrm{Ta}$ and $\mathrm{Nb}$, with formulae such as $\mathrm{ABO}_{3}$ (seventh $\mathrm{O}$ totally absent) and $\mathrm{AB}_{2} \mathrm{O}_{6}$ (seventh $\mathrm{O}$ and half the $\mathrm{A}$ cations absent). It seems possible that a distinction should be drawn between these $\mathrm{A}^{2+} \mathrm{B}^{5+}$ pyrochlores for which the $\mathrm{BO}_{3}$ framework description seems more appropriate, and the $\mathrm{A}^{3+} \mathrm{B}^{4+}$ type, whose properties are more in keeping with those of the generality of fluorite-related superstructures considered here.

2.2 STRUCTURES INVOLVING PARTIAL ANION VACANCY ORDERING. - 2.2.1 Structures with fully ordered cations and partially ordered anion vacancies are rare, since usually the two effects are linked. However, an example is $\mathrm{Na}_{2} \mathrm{U}_{2} \mathrm{O}_{7}$, which has a 
distinct fluorite-related structure in which anions are distributed on two sets of sites, one of which contains a random population of vacancies [23].

2.2.2 Partially ordered cations and anion vacancies may occur whenever an ordered fluorite-related phase exhibits a range of composition, as in the case of some pyrochlores such as $\mathrm{Gd}_{2} \mathrm{Zr}_{2} \mathrm{O}_{7}$. A detailed study of density, lattice parameter and $\mathrm{X}$-ray diffraction intensities supported by electron diffraction would be needed to determine the nature of the disorder in non-stoichiometric pyrochlores : No such study appears to have been made.

2.2.3 The defect fiuorite phase may contain a relatively high concentration of vacancies, so that vacancy interaction and ordering effects may be expected to occur. Non-linear variation of anionic conductivity with vacancy concentration has been attributed to such order [24]. Since the stabilised zirconias of industry are in this class, an understanding of the ordering could be of value in predicting and controlling such properties as conductivity, precipitation phenomena and destabilisation.

The most direct evidence for partial ordering comes from diffraction studies. Diffuse reflections are obtained in addition to the sharp Bragg reflections from the fluorite structure. This diffuse intensity appears in single crystal X-ray photographs, but may be seen more readily in electron diffraction. For a variety of defect fiuorite phases at about $10 \%$ vacancy concentration, the diffuse patterns, though complex, are remarkably similar and differ mainly in scale. Such scattering could arise from statistically homogeneous medium-range ordering of cations or anion vacancies, or from fully-ordered microdomains coherent with the fluorite matrix with the superlattice reflections broadened by particle size effects.

The lime-zirconia and lime-hafnia systems have been studied in some detail in our laboratory, and the observed electron diffraction patterns have been satisfactorily matched by those calculated for domains of monoclinic $\varphi_{1}, \mathrm{Ca}(\mathrm{Zr}, \mathrm{Hf})_{4} \mathrm{O}_{9}$, about $30 \mathrm{~A}$ in diameter in all possible orientations coherent with the fluorite matrix [25]. In this case, the appearance of appropriately scaled mottled contrast in darkfield micrographs imaged with the diffuse reflections supports the heterogeneous model. Also, on annealing, these microdomains grow until individual crystals of $\varphi_{1}$ can be identified.

However, there are some difficulties. The diffuse scattering is virtually unchanged for $\mathrm{ZrO}_{2}\left(\mathrm{HfO}_{2}\right)$ specimens containing from 10 to 20 mole $\% \mathrm{CaO}$, which, according to the above model, requires marked cation segregation to be present in those compositions far removed from that of $\varphi_{1}$. Since the diffuse intensity is apparent in samples quenched from the melt, and since cation diffusion is very slow at the ordering temperature of $\varphi_{1}$, this implies the formation of segregated microdomains well above the ordering temperature. The segregation and ordering of the more mobile anion vacancies alone is scarcely credible in this system because of the strong anion-cation correlations imposed by both size and ionic charge.

The diffuse scattering observed from yttria-zirconia samples of similar vacancy concentration is less well explained by the microdomain model. The scale of the diffuse features is inconsistent with $\varphi_{1}$-type ordering. The only ordered phase known to occur in this system is $\mathrm{Zr}_{3} \mathrm{Y}_{4} \mathrm{O}_{12}$ [13]. Microdomains of this phase give quite different diffuse patterns, which in fact may be observed for specimens of vacancy concentration near $13 \%$. At higher concentrations $(\sim 15 \%)$, diffuse scatter due to domains of $\mathrm{Y}_{2} \mathrm{O}_{3}$ (C-type) structure occurs.

In principle, a set of order parameters can be derived from the diffuse intensity [26, 27], but this approach is descriptive rather than explanatory, and becomes very cumbersome when correlations over $10 \mathrm{~A}$ or more are considered. Alternatively, a few short-range restrictions (i.e. interaction energies) may be specified, and varied, from which extended sets of order parameters can be calculated by methods developed by Dr. A. Verhagen in our laboratory. Initially, anion vacancies alone, at $10 \%$ concentration, were considered, with three or four restrictions derived from the known ordered structures, e.g. vacancy separations less than $1 / 2\langle 111\rangle_{\mathrm{f}}$ are prohibited, while the $1 / 2\langle 111\rangle_{\mathrm{f}}$ separation is energetically favourable. Electron diffraction patterns have been calculated which match the observed patterns qualitatively provided that no less than 25 order parameters are included.

At this stage, the model is somewhat naive, and ignores cation ordering completely, although this possibly is valid for $\mathrm{Y}$ and $\mathrm{Zr}$ with similar scattering factors. However, the initial success justifies elaboration of this approach and its application to other physical properties.

3. Conclusion. - Electron microscopy and diffraction has proved to be a powerful aid to the study of ordering in fluorite systems. Nevertheless, further structural studies are required to achieve an understanding of the principles underlying superstructure formation in these systems, and to provide an adequate description of the defect fluorite phase itself.

\section{References}

[1] Levin, E. M., Robins, C. R. and McMurdie, H. F., Phase Diagrams for Ceramists, M. K. Reser, ed. (Am. Ceram. Soc.) 1969.
[2] Bevan, D. J. M. and Kordis, J., J. Inorg. Nucl. Chem. 26 (1964) 1509.

[3] Marezro, M., Acta Crystallogr. 20 (1966) 723. 
[4] Bartram, S. F., Inorg. Chem. 5 (1966) 749.

[5] ThORNBer, M. R. and BeVAn, D. J. M., J. Solid State Chem. 1 (1970) 536.

[6] Bystróm, A., Arkiv. Kemi, Min. Geol. 18A (1944) No. 21.

[7] Pyatenko, Yu. A. and Pudovkina, Z. V., Kristallografia 6 (1961) 196.

[8] Thornber, M. R., Bevan, D. J. M. and Summerville, E., J. Solid State Chem. 1 (1970) 545.

[9] Von Dreele, R. B., Eyring, L., Bowman, A. L. and YarNElL, J. L., Acta Crystallogr. B 31 (1975) 971.

[10] Rossell, H. J. and Scotr, H. G., J. Solid State Chem. 13 (1975) 345 .

[11] Allpress, J. G., Rossell, H. J. and Scott, H. G., J. Solid State Chem. 14 (1975) 264.

[12] Rossell, H. J., J. Solid State Chem. 19 (1976) 103.

[13] Scorr, H. G., Acta Crystallogr. B 33 (1977) 281.

[14] Hoskins, B. F. and Martin, R. L., J. Chem. Soc. Dalton (1975) 576, (1976) 676.

[15] Pyatenko, Yu. A., Zhutr. Strukt. Khim. 4 (1963) 708, Dok. Akad. Nauk SSSR 173 (1967) 634; Izvest. Akad. Nauk SSSR̈ Neorg. Mat. 7 (1971) 630.
[16] Yovanovitch, O. and Delamarre, C., Mat. Res. Bull. 11 (1976) 1005.

[17] Brisse, F. and Knop, O., Can. J. Chem. 46 (1968) 859.

[18] Shannon, R. D. and Sleight, A. W, Inorg. Chem. 7 (1968) 1649.

[19] Perez y Jorba, M., Ann. Chim. 7 (1962) 479.

[20] Areshin, E. and Roy, R., J. Am. Ceram. Soc. 45 (1962) 18.

[21] Hervieu, M., Michel, C. and Raveau, B., Bull. Soc. Chim. France (1971) 3939.

[22] Allais; G., Michel, C. and Raveau, B., C. R. Hebd. Séan. Acad. Sci. 274 (1972) 1625.

[23] Kovba, L. M., Ippolrtova, E. A., Simanov, Iu. P. and SiISYN, V. I., Dokl. Akad. Nauk SSSR 120 (1958) 1042.

[24] CARTER, R. E. and ROTH, W. L., in Electromotive Forcè Measurements in High Temperature Systems, C. B. Alcock, Ed. (Inst. of Mining and Metallurgy, London) 1968, 125.

[25] Allpress, J. G. and Rossell, H. J., J. Solid State Chem. 15 (1975) 68.

[26] Cowley, J. M., J. Appl. Phys. 21 (1950) 24.

[27] Warren, B. E., X-ray Diffraction (Addison-Wesley Publ. Co. Inc. Reading, Ma., USA) 1969. 